Article

\title{
Sustainable Technologies for the Transition of Auditing towards a Circular Economy
}

\author{
Joshua Onome Imoniana ${ }^{1, *}$, Washington Lopes Silva ${ }^{1}$, Luciane Reginato ${ }^{1}{ }^{1}$, Valmor Slomski ${ }^{1}$ \\ and Vilma Geni Slomski ${ }^{2} \mathbb{D}$ \\ 1 Management and Accounting, School of Economics, University of Sao Paulo, São Paulo 05508-010, Brazil; \\ washlosil@gmail.com (W.L.S.); lucianereginato@usp.br (L.R.); valmor@usp.br (V.S.) \\ 2 FECAP—Fundação Escola de Comércio Álvares Penteado, São Paulo 01005-010, Brazil; vilma.geni@fecap.br \\ * Correspondence: josh.imoniana@usp.br; Tel.: +55-11-99244-9055
}

Citation: Imoniana, J.O.; Silva, W.L.; Reginato, L.; Slomski, V.; Slomski, V.G. Sustainable Technologies for the Transition of Auditing towards a Circular Economy. Sustainability 2021 13, 218. https://doi.org/10.3390/ su13010218

Received: 19 November 2020 Accepted: 14 December 2020 Published: 28 December 2020

Publisher's Note: MDPI stays neutral with regard to jurisdictional clai$\mathrm{ms}$ in published maps and institutional affiliations.

Copyright: (C) 2020 by the authors. Licensee MDPI, Basel, Switzerland. This article is an open access article distributed under the terms and conditions of the Creative Commons Attribution (CC BY) license (https:// creativecommons.org/licenses/by/ $4.0 /)$.
Abstract: This study examines the relationships between sustainability technologies, auditor transition, and circular economy models. Circular economy (CE) has been visited in recent studies as a matter of necessity to procure answers to pressing issues that befalls our society, aimed at the survival of the human species. While doing so, there has been little emphasis placed on sustainable technologies that will usher auditors into the new era. Data were constructed from a symposium organized by the Institute of Internal Auditors (IIA), where scholars and practitioners addressed the future of auditing technology, regarding, in particular, the International Social and Environmental Accreditation and Labeling (ISEAL) database official website and also interviews with experts dealing day to day with sustainability and circular economy. Discourse analysis assisted in working with these groups of data. Our findings identified 12 different relational types in our analysis, thus signaling upward trends in the preparedness of auditors in boosting sustainable technologies towards a circular economy environment. Additionally, our findings demonstrate the significant uptake of innovative tools implemented for new-generation technologies in order to enhance auditing. The findings of this study have implications for academia and practice which are aimed at technological preparedness for the transition of auditing towards CE. Finally, this paper contributes by summarizing the debate and speculations around the technologies that are driving auditing to $\mathrm{CE}$.

Keywords: sustainable; technology; auditing; sustainable economy; circular economy

\section{Introduction}

Auditing is going through many innovations in the era of circular economy (CE) that are happening, most importantly, because of anthropogenic climate change, which poses an apparent threat to the survival of the human species and drives current economies. Climate change alters economic logic because it replaces production with sufficiency: reuse what you can, recycle what cannot be reused, repair what is broken, remanufacture what cannot be repaired [1]. De facto, this is so because all parts of life seem to be moving in this direction as we become more environmentally conscious. Therefore, an organizational assurance function, such as auditing, cannot be an exception.

It is noteworthy that many countries are still at the embryonic stage of implementationthat is to say that the sustainable technologies that support environmental auditing are very scarce and remain unexplored. Notwithstanding this, concerning the theoretical contributions received to date, it is imperative to note that $\mathrm{CE}$ contributes to the sustainable development of economies. Circular economy is recommended as an approach towards economic growth that is in line with sustainable environmental and economic development [2]. However, aspects relating to sustainability assurance or cleaner production auditing are yet to receive the attention they deserve. This assurance is probably still considered voluntary in most economies. Research conducted by Liu and Bai [3] showed 
that $69.5 \%$ of firms have not adopted cleaner production auditing and $92.2 \%$ have not established a special circular economy management department.

In fact, this means that auditing, as an assurance technology, must converge, rethink, and realign with the key drivers of $\mathrm{CE}$, such as labor, most importantly, as well as material resources and overhead costs. That does not even include societal cultures and values, environmental benefits, social guarantees and security, value recovery, and legislative orientation.

There are studies that concern leadership of this initiative. According to Kirchherr et al. [4], the circular economy concept is much discussed in the European Union (EU), but only limited progress has been made so far regarding its implementation. Most scholarly studies blame this on various technological barriers.

Notwithstanding the pace of development, this handful of technologies is certainly very relevant for the sustainability of the work of auditors in this current environment. This will continue to pave the way for opportunities in academia and also open opportunities for additional standard settings to follow suit.

Until very recently, auditing engagement teams have had to develop knowledge statements considering industrial specialization. These industries or businesses are found in the banking and finance, energy and gas, building and construction, non-for-profit, government parastatal, cooperative, and grocery sectors, to mention just a few. Today, assurors must have competencies in sustainable technologies to address key barriers in social, economic, environment, and technological change. They must also cover consumerism hindrances, besides negotiating fees with the client, who bears the brunt for additional costs of recovery, and the management of reverse logistics.

Auditors of financial statement have, until this moment, audited significant application systems tied to Enterprise Resource Planning (ERP), with a focus on a general ledger. The focus on new technologies has changed this approach. This is a sort of reverse auditing application. This is a broad category of applications and technologies for gathering, providing access to, and analyzing data for the purpose of helping enterprise users make better business decisions [5].

Thus, in respect to the abovementioned points, our main concern is understanding the role of technologies in ushering auditing towards CE. In fact, since the introduction of sustainability auditing, the issue of technology and CE approaches has started to come into the limelight among investors, regulators, and accountants, to mention but a few. Therefore, the purpose of this study is to provide an understanding of the relationships between sustainability technologies, auditor transition, and circular economy models.

Thus, investigating how technology ushers auditing towards CE is important for various reasons. Firstly, it enables one to comprehend how fifth-generation technologies, which are being implemented at present, are paving ways for the sixth generation considering $\mathrm{CE}$ concepts. Secondly, it is important to comprehend how the preparedness of the auditing and assurance functions in organizations is being updated in circular economy models (CEM). Auditors, among other management functions, have been viewed as lagging behind in implementing technological resources. Voluntary Sustainability Standards (VSS) are also generally seen as lagging behind technological trends [6]. Lastly, as the gap in academia is expressive, the literature on the relationships between sustainable technology, auditing, and $C E$ will provide a concise and empirical setting to address the needs of academia and also practitioners.

The rest of this paper is organized as follows. The next section outlines a background of the existing literature in the area and presents the research premise. Section 3 provides a description of the research methodology and Section 4 provides data construction. Section 5 analyzes the data, the results, and the main findings. Section 6 paves the way for a discussion that capitalizes on the reflexivity of the results with a focus on the main stakeholders. Section 7 provides the final conclusions of the paper. 


\section{Background}

\subsection{Cornerstone of Circular Economy}

The cornerstone of circular economy (CE) is reuse and not tolerating waste in the value chain. Its main essence is being restorative and regenerative in view of ensuring continuity. Therefore, the change in the product chain becomes clear to all players as they challenge the archaic development modes that do not seem to be sustainable nowadays. According to Patwa et al. [7], the core of CE has changed the development mode of traditional individual economy. A circular economy is like a lake. The reprocessing of goods and materials generates jobs and saves energy while reducing resource consumption and waste. Cleaning a glass bottle and using it again is faster and cheaper than recycling the glass or making a new bottle from minerals [1].

As an architect, I know that it takes more labor and fewer resources to refurbish buildings than to erect new ones [1]. Thus, this means reverse logistics are at work which gives value to the use of labor. Certainly, this is an era that places more importance on labor.

Circular economy is based on environmental, economic, and social dimensions and aims to ensure sustainable development at each step of production creation, transformation, and conversion by creating a closed-loop economy [8]. The authors further expand the social pillar to include the dimensions of human well-being, healthy ageing, health, and social justice. In the same line of thought, $\mathrm{CE}$ is "an economic model wherein planning, resourcing, procurement, production and reprocessing are designed and managed, as both process and output, to maximize ecosystem functioning and human well-being" [9] (p. 369). In order to maintain this said well-being, firms have their various ways of contributing to the society in which they live. Firm contribute to the achievement of social and environmental objectives through the integration of corporate social responsibility with strategic investment in management tools and operations [10].

Similarly, in light of the aforementioned points, one is able to envisage the optimization of value circulation. This is connected to the strong influence of circulating the product per se among peers and consumers at large, using products as a service to encourage the adoption of CE practices in emerging economies [7].

In the same vein, excessive consumption is questioned in a transition towards circular economy. The question that needs to be answered is how can you claim to respect your neighbors who are less fortunate if you indulge in lavishness? This is an inherent tension (e.g., excess, prestige, self-gratification, uniqueness) in relation to improving ethical/sustainable consumption practices within the luxury sector [11].

\subsection{Relationships between Technologies and Circular Economy Models}

Circular economy models (CEMs) now demand rethinking innovative technologies and the value-aggregated business functions by holding to fewer material resources in the organization as the modus operandi changes. Technology does lie now in supporting rethinking labor and not material resources in the first place in value chains of production, thereby prioritizing labor usage, economies, and environmental degradation. Thus, following Deloitte [12], Nikonorova et al. [8], and Zero Waste Scotland [13], we built Figure 1 to expatiate on business models showing that management and control functions have changed over time in order to address their innovative roles in effective $C E$. The current scenario calls for CEMs such as manufacturing a waste-free recyclable loop, managing take-back reverse logistics streams, managing incentivized returns for refunds, and manufactures making a full repair so that you are unable to distinguish a repaired product from a brand new one. Other models considered are refurbishment to put products in working condition, remanufacturing to guarantees plain functionality, and recycling to a new product. In the same vein, businesses may decide to use hiring and leasing and peer-to-peer public collaboration for consumption. 


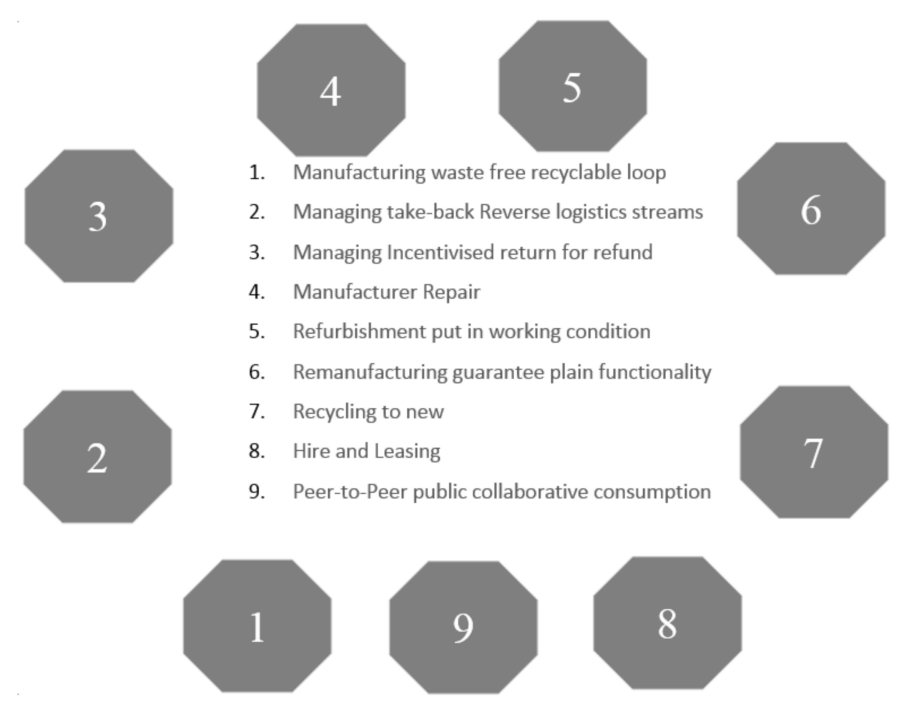

Figure 1. Circular economy models.

The current models tend to take into consideration environmental awareness, mainly circular economy, which upholds the zero-waste idea. These models also put into practice the collaborative planning, execution, and reporting of business operations by peers, competitors, suppliers, and customers, undermining differences in view of cultivating an enviable nature and better world to live in.

Many companies, such as Danone, H\&M Group, and DS Smith, are already leveraging these new technologies to design waste and pollution out of their value chains while keeping products and materials in use to create positive economic, environmental, and societal impacts [14]. The same authors observed that System Applications and Products (SAPs) are leading to technological approaches that both guide and accelerate circular solutions.

Similarly, drawing upon the schema proposed by Sarkis and Zhu [15], the technology industry calls for attention to be given to China. They observed that electronic wastes are of concern largely due to the toxicity and carcinogenicity of some of the substances being processed improperly.

Furthermore, the technologies are not farfetched, as some robust approaches of advanced technologies aiming at consolidating circular economy are under implementation. This ranges from digitalization technologies; the Internet of Things (IoT) being used in all processes; and Artificial Intelligence (AI) to be used to dynamize operational and management processes, remote sensing, and tracing, to mention just a few. Hatzivasilis et al. [16] worked on the Industrial Internet of Things as an enabler for a circular economy Hybrid Protocol (Hy-LP). A novel Industrial Internet of Things (IIoT) protocol, evaluated on a wind park's Software-Defined Networking/Network Functions Virtualization (SDN/NFV)-enabled 5G industrial network, reached the conclusion that the developed systems are evaluated on a common testbed, demonstrating that the proposed solution is around 10 times faster for the same Central Processing Unit (CPU) usage level while consuming seven times less memory. Digital technologies have enabled the formulation of multiple Product Service Systems (PSSs) with considerable economic, environment, and societal benefits [17]. Digital Technologies (DTs), such as Internet of Things, big data analytics, and artificial intelligence, are seen as the main supporters of CE transition because they are facilitating and initiating the implementation of end-of-life strategies [18]. Therefore, this affirms the promising paradigm that supports CE models.

In particular, in this period of COVID-19 pandemic, coincidentally Information and Communication Technologies (ICT) have been implemented to support businesses, with this coincidentally serving as a means to usher in circular economy. The demand for communication software such as Microsoft Teams and Zoom has been unprecedented, 
as hundreds of millions of people have abruptly been required to work remotely from home [19].

Moreover, in the era of big data, a bigger storage of data has to be constituted in the base of the circular economy model (CEM) with all the company's data in an integrated format with the technology available to enhance manipulation from all aspects of the organization. Certainly, this would need users to be trained to adequately use resources and take advantage of them.

Thus, in the same line of thought as that above, CE is frequently viewed as an operationalization for businesses to implement the much-debated concept of sustainable development [20]. However, according to Geissdoerfer et al. [21], the relationship of CE with sustainable development has not yet been clarified by the literature.

As put forth by Raschke and Walsh [22], increasingly organizations connect their on-premises infrastructures to cloud-based technologies, both from a Software-as-a-Service (SaaS) and an overarching infrastructure perspective. While organizations have developed strategies for securing data privacy and security for their on-premises environments, their adoption of cloud-based technologies to streamline business operations changes their ability to control user access to resources.

In the same vein, the digitalization of the organizational processes is being seen as one of the drivers of CE. Antikainen et al. [23] noted that digitalization can boost the transformation towards a more sustainable circular economy. This is true inasmuch as it reduces duplicate document originations, management report generation, and multiple authorizations that call for the attention of the auditors.

Overall, practitioners are working closely to harness technological resources that would usher in CE. Various groups are discussing the issues of databases, application systems, security, and even networking with the hope of reaching an agreement on the sustainability of their use.

\subsection{Transition of Cleaner Production Auditing towards CE}

Auditing, like all sciences that adopt an epistemological approach to the critical study of principles and practices, consists of assuring information records, analyses, and reporting. Additionally, auditing is termed as a process of systematic evaluation of accounting records and related operations to determine adherence to accounting principles, current rules, prescribed business policies and issued standards [24]. In the field of voluntary ISO standards, auditing is defined as a "systematic, independent and documented process for obtaining objective evidence and evaluating it objectively to determine the extent to which the audit criteria are fulfilled" [25].

In the same vein, Cleaner Production (CP) auditing derived from sustainability accounting aims to safeguard assets by assessing and monitoring the effectiveness of the enforcement rules in production chains. Sustainability accounting entails treating business transactions in a suitable manner while considering economic, environmental, and social factors to primarily safeguard assets and also protect the interest of society at large [26].

Boyle [27] observed that there are many facets to cleaner production, including waste auditing and waste minimization, lifecycle assessment, design for environment, industrial ecology, zero emission, resource suitability and cascading, and responsibilities for consumption and waste.

Consequentially, through cleaner production auditing and technological innovation, enterprises have achieved both favorable economic and environmental records. Enterprises using toxic or hazardous materials are subject to mandatory cleaner production auditing (Article 28) [28]. The benefit of this approach is that it portrays a holistic view concerning the effectiveness of the firm's internal controls.

$\mathrm{CP}$ auditing, which is likened to waste auditing when explained with the Plan, Do, Check, and Act (PDCA) cycle, draws on the continuous betterment of the production chain by tracking where the model has gone wrong. It is a multidisciplinary type of assurance inasmuch as it affects all aspects of the organization. 
The main tasks of procedural audit draw upon the description and mapping of inputs to the operational processes, after which one is able to identify cleaner production improvements, if any. Thereafter, one calculates all the total environmental costs and quantifies the wastes based on expert opinion. The last aspect has to do with the characterization of waste streams involving environmental impacts in view of minimizing the waste itself, which is the aim of the audit.

Similarly, with the transition to $\mathrm{CE}$, every work of life engages auditors, accountants, engineers, product and process designers, planning specialists, architects, lawyers, marketing salespeople, and service professionals. Dobes [29] distinguishes between auditing and accounting approaches in the promotion of cleaner production and argues that auditing approaches are not sufficient for the completion of the learning needed for the integration of cleaner production into the practice of an enterprise. This, in effect, confirms the multidisciplinarity of the expertise needed to assess the business functions in the production chain.

The issues of concern in auditing transition to CE concern the technologies that drive the changes. These facets of the changes are naturally assessed in view of monitoring the performance of the management. This makes the specialists' participation in the assurance process very unique.

It is noteworthy, with the restrictions posed by COVID-19 when face-to-face approaches are not possible, that exception audit arising from disruptions to audit activities draws on other complementary procedures. These approaches have employed ICT resources that have evolved over time in Generation $(G)$ technologies.

In Peltier and Ashford [30], three-dimensional technological management assessment models are brought to light. They are explained as follows: (1) end of pipe versus CP approaches (a) input substitution, (b) process change, (c) waste recovery (d) product design); (2) diffusion versus innovation (a) incremental environmental innovation through the diffusion of well-known clean technologies, (b) the transfer of a clean technology commonly adopted in a particular industrial sector to a new industry or an innovative combination of several incremental innovations, (c) a truly new break through); (3) targeting primary, secondary, and ancillary processes (a) primary processes yield the basic functional form of the product, such as forming or casting apart from material; (b) secondary processes involve the application of a functional finish, such as non-corrosive or aesthetically pleasing finishes; (c) ancillary processes do not affect the characteristic of the product and are usually less fundamental for the whole manufacturing process).

\section{4. $5 \mathrm{G}$ and $6 \mathrm{G}$ in $\mathrm{CE}$}

Mobile wireless communication networks have grown over time. The networks have evolved from 1G-analog, 2G-digital, 3G-multimidia, 4G-integration with fixed internet and $5 \mathrm{G}$ adds perfect wireless, world wide web (wwww). Generation $(\mathrm{G})$ generally referred to a change in the nature of the system, speed, technology and frequency [31]. The fifth generation of data communication network technology involves mostly the use of mobile equipment that succeeds other generations with the increment of qualitative data analysis. The fifth generation of data permits almost $1001 \mathrm{Gbit} / \mathrm{s}$ thus allowing the capacity of connecting approximately a million of equipment per kilometer.

The $6 \mathrm{G}$ is intended to integrate $5 \mathrm{G}$ with the satellite, aiming to give the whole world full coverage. In fact, it will be 100 times faster and broader than the 5G counterpart. It optimizes connectivity, security with the use, intelligence with the maximization of AI, energy efficiency, data rate, and latency with its enabling technologies. Besides this, cyber and physical layer security issues within networks permeates it. As a result, for wireless computing among individuals and communities, privacy leakage is a predominant concern caused by perpetual data uploading, caching, and transmitting [32]. In the same line of thought, [33] observed that the latency, reliability, and data rate requirements of the applications involved in multiway virtual meeting with holographic projection, virtual and augmented reality (VAR), brain communication interface, teleportation, and remote 
surgery indicate that the applications are clearly beyond the capacity of the existing 5G systems. Eventually, AI and its enabling resources will be at the forefront of $6 \mathrm{G}$.

In effect, $6 \mathrm{G}$ environment creates room for integration of comfort between humans and machines, with tightened security to ensure trusted communication and pronounced intelligence which are artefacts that converge to circular economy models. Similarly, in this same wave of comfort, calls for the benefits of auditing to keep the users at peace with technologies such as blockchain. Blockchain technology will likely play a major role in securing and authenticating future communication systems thanks to the inherent advantage of distributed ledger technology. It offers a number of benefits including decentralization, transparency with adequate privacy and alteration-proof authentication [33].

\subsection{The ICT Move of CE Audit}

From its inception, ICT has accelerated the auditing accompaniment of business assurance. Thus, in current scenarios, Information Communication and Technology tends to drive the sustainable technologies for the transition of auditing towards the circular economy. In fact, without which, it would be barely impracticable.

There are lots of potential usage of ICT in the audit that sustains CE. Castka et al. [19], discussing remote auditing observed: Teleconferencing using video and/or audio; Sharing of data; Assessment of documents through remote sharing; Teleconferencing or other means; Video and/or audio streaming from remote locations; Records of video and/or audio stills and/or screenshots.

In situations when internet connection does not allow for a stable interaction between the auditor and auditee generally, documentary transfers are recommended to enhance evidence gathering processes. Generally, we recognize the possibility of both on- and off-line ICT options [19].

Thus, in a move to exploring the way forward, studies concerning big data which is the Achilles heel of CEM ought to be treated with care. Three areas of investigation are identified: new performance indicators based on social media and big data; governance of social media and big data information resources; finally, social media and big data's alteration of information and decision-making processes [34].

Technologies are quite relevant to support auditing towards CE. This bears on new business models, the adoption of Environmental Management Systems (e.g., ISO 14001), a friendlier context (fiscal, legal, organizational), and stronger support from supply chain agents and consumers as drivers for CE successful adoption [35].

ISO 14001 international standard establishes the requirements for Environmental Management Systems (EMS), including the organizational structure and the responsibilities; the planning of the activities; the definition of practices, processes, and procedures; the allocation of resources to plan, implement, check and improve (PDCA) the environmental policy and improve environmental performance [36].

Overall, in order to guide the current study, we establish the following premise: the relationship between auditing and circular economy is built on the rock of sustainable technologies which is yet under development in various facets of organization.

\section{Methodology}

This study adopted an interpretative approach based on a constructivist perspective. Social constructivism emphasizes the importance of culture and context in understanding what occurs in society and constructing knowledge based on this understanding [37]. It draws mostly on the lived experiences of the individuals that constitute our data corpus.

In contrast to some discourse analysis studies, this work is not aimed at written texts, but the dialogical aspects. De facto, it is a qualitative approach that draws upon discourse analysis based on discourse theory (DT). The discursivity of a social interaction would explain the political agenda of the powerful actors [38]. This also extends on the approaches deliberated on by Bourdieu [39] that questions patterns of use of even most 
radical technology in care and ways of living in the homes. The central importance of discourse is constructing social life [40].

This is in line with Castka et al. [19], who investigated a qualitative study, and data were collected from publicly available sources in order to inductively analyze how individual VSS have adjusted their certification services in response to travel bans and lockdowns.

\section{Data Construction Procedures}

Data were constructed from three sources. Firstly, data were gathered from the symposium organized by Institute of Internal Auditors (IIA) of Brazil [41] on Webinar addressing the future of auditing technology. The deliberations took approximately three hours recording. The speakers were two renowned scholars in the area of technology and accounting information systems from Rutgers University and the University of São Paulo and three practitioners from the Big four audit firm and also the Brazilian Marine. The moderator was a chief internal auditor from a technology-based wholesale banking. Even though this data is available in the corporate website of the IIA, additional authorization was sort from the institute for the use of the recordings. This contributes well in relation to the data that embraces the concerns of circular economy particularly in the period of COVID-19 lockdown.

Secondly, apart from the aforementioned source, we also obtained data from International Social and Environmental Accreditation and Labeling (ISEAL)'s database official website (http:/ / www.standardmap.org). ISEAL [42] assembles information on global membership organization for credible sustainability standards. Search engines limited to technology for cleaner production in first place and in the second-place technologies for audit in the CE. Noteworthy that in the second search there were little or no results as the words have been least explored.

Last but not the least, we also interviewed 10 experts in the field in order to triangulate our constructed data. The individuals were represented by their initials, as no authorization was given to reveal their names. As we are yet to fully escape the COVID-19 lockdown, our respondents were conducted through virtual contacts. Invitations were sent to the interviewee electronically mentioning the topic and requesting an interview schedule. After which a schedule meeting was made. A zoom link was sent to the interviewee with date and time, along with an authorization document to record the interview. In effect, the interviews lasted $50 \mathrm{~min}$ approximately each. At the beginning of which the presentation of the research was carried out and then the interviewee was asked to discuss the topic informed at the time of the invitation. The interviewee freely expressed his or her opinion and experiences in the organization in which he or she operates. The recorded interview was duly transcribed and filed as part of the research documents using the Amberscript software.

Overall, the data constructed contained details that assisted in providing answers to our argument for technologies that ushers auditors towards CE. The profile of the respondents can be observed in Figure 2.

\begin{tabular}{|c|c|c|c|c|}
\hline Respondent & Gender & Age & Experience & Profile \\
\hline KAG (E1) & F & 31 & 6yrs & $\begin{array}{l}\text { A Leader in environmental Audit projects. Presently performs services in cleaner production audit. ISO } 14001 \text { and } \\
\qquad 9001 \text { certified. }\end{array}$ \\
\hline$J M F(E 2)$ & $F$ & 45 & $12 y r s$ & Accountant. Senior manager in Big-four auditing firm. Involved in circular economy projects. \\
\hline ORA (E3) & M & 42 & 25yrs & $\begin{array}{c}\text { Accountant with specialisation in AIS. Presently a senior executive of one of the } 2 \text { nd largest IT and IS provider in the } \\
\text { world. He was a senior manager of a Big-four auditing firms covering the areas of IT governance and circular economy } \\
\text { projects. }\end{array}$ \\
\hline GPG (E4) & $M$ & 31 & $4 y$ rs & Geologist and PhD Candidate. Practitioner in Sustainability and Environmental Control. \\
\hline TAA (E5) & $M$ & 35 & $10 \mathrm{yrs}$. & Accountant. IT auditor responsible for continuous auditing in the Marine of Brazil \\
\hline CRB (E6) & M & 43 & $23 y$ rs & $\begin{array}{l}\text { Accountant. Presently owner of accounting firm, was a senior manager of a Big-four auditing firms covering the Global } \\
\text { Sustainability Services where he served for } 16 y \text { rs }\end{array}$ \\
\hline$J P A(E 7)$ & $M$ & 40 & $13 y$ rs & Accountant. Chief Internal Auditor in one of the topmost two banks in Brazil \\
\hline$V A D(E 8)$ & M & 40 & $16 y$ rs & Administrator. Senior Audit Manager in one of the topmost five banks in Brazil. \\
\hline$H O D(E 9)$ & $M$ & 44 & $24 y r s$ & 13 years as Chief Internal Auditor in one of the 2 nd largest banks in Brazil and 11 years in KPMG. \\
\hline REB (10) & $M$ & 45 & $22 y r s$ & 4 years Chief IS Auditor in one of the 4th largest banks in Brazil and 18 years in $E Y$. \\
\hline
\end{tabular}

Figure 2. Profiles of the respondents. 


\section{Analysis}

Our analysis of the data consists of using discourse analysis supported by discourse theory (DT) to work on the sociological, economic, and political significance to provide an understanding of the relationships between sustainability technologies, auditor transitions, and circular economy models. This follows Laclau and Mouffe [38], who highlight that discourse reflects the meanings society gives, and also Imoniana and Imoniana [43], who adopted discourse analysis, highlighting sociological, psychological, and political interpretations to critique the data constructed in their study.

We ran the NVivo qualitative software to assist in analyzing the data, showing the word count of the ones most mentioned in our interviews in Table 1.

Table 1. Most mentioned words from the interview comments.

\begin{tabular}{|c|c|c|c|}
\hline Word & Length & Count & Weighted Percentage \\
\hline audit & 5 & 65 & $1.08 \%$ \\
\hline economy & 7 & 48 & $0.80 \%$ \\
\hline circular & 8 & 41 & $0.68 \%$ \\
\hline technology & 10 & 41 & $0.68 \%$ \\
\hline auditing & 8 & 40 & $0.67 \%$ \\
\hline business & 8 & 37 & $0.62 \%$ \\
\hline sustainability & 14 & 26 & $0.43 \%$ \\
\hline model & 5 & 21 & $0.35 \%$ \\
\hline process & 7 & 21 & $0.35 \%$ \\
\hline controls & 8 & 20 & $0.33 \%$ \\
\hline environmental & 13 & 19 & $0.32 \%$ \\
\hline processes & 9 & 19 & $0.32 \%$ \\
\hline interviewee & 11 & 17 & $0.28 \%$ \\
\hline sustainable & 11 & 17 & $0.28 \%$ \\
\hline innovation & 10 & 15 & $0.25 \%$ \\
\hline production & 10 & 15 & $0.25 \%$ \\
\hline external & 8 & 14 & $0.23 \%$ \\
\hline management & 10 & 14 & $0.23 \%$ \\
\hline based & 5 & 13 & $0.22 \%$ \\
\hline blockchain & 10 & 13 & $0.22 \%$ \\
\hline cloud & 5 & 13 & $0.22 \%$ \\
\hline environment & 11 & 13 & $0.22 \%$ \\
\hline models & 6 & 13 & $0.22 \%$ \\
\hline information & 11 & 12 & $0.20 \%$ \\
\hline resources & 9 & 12 & $0.20 \%$ \\
\hline waste & 5 & 12 & $0.20 \%$ \\
\hline financial & 9 & 11 & $0.18 \%$ \\
\hline social & 6 & 11 & $0.18 \%$ \\
\hline compliance & 10 & 10 & $0.17 \%$ \\
\hline tools & 5 & 10 & $0.17 \%$ \\
\hline cleaner & 7 & 9 & $0.15 \%$ \\
\hline concept & 7 & 9 & $0.15 \%$ \\
\hline
\end{tabular}


Table 1. Cont.

\begin{tabular}{cccc}
\hline Word & Length & Count & Weighted Percentage \\
\hline value & 5 & 9 & $0.15 \%$ \\
\hline Brazil & 6 & 7 & $0.12 \%$ \\
\hline change & 6 & 7 & $0.12 \%$ \\
\hline mapping & 7 & 7 & $0.12 \%$ \\
\hline
\end{tabular}

According to the word counts, audit and auditing (1.08\% and $0.67 \%$, respectively) are the most cited words, followed by technology $(0.68 \%)$ and circular + economy $(0.68 \%+0.80 \%)$. This confirms the understanding of the relationships of technology as it orientates the design of auditing towards CE.

This is further expatiated on in the most commented words, shown as a cloud in Figure 3.

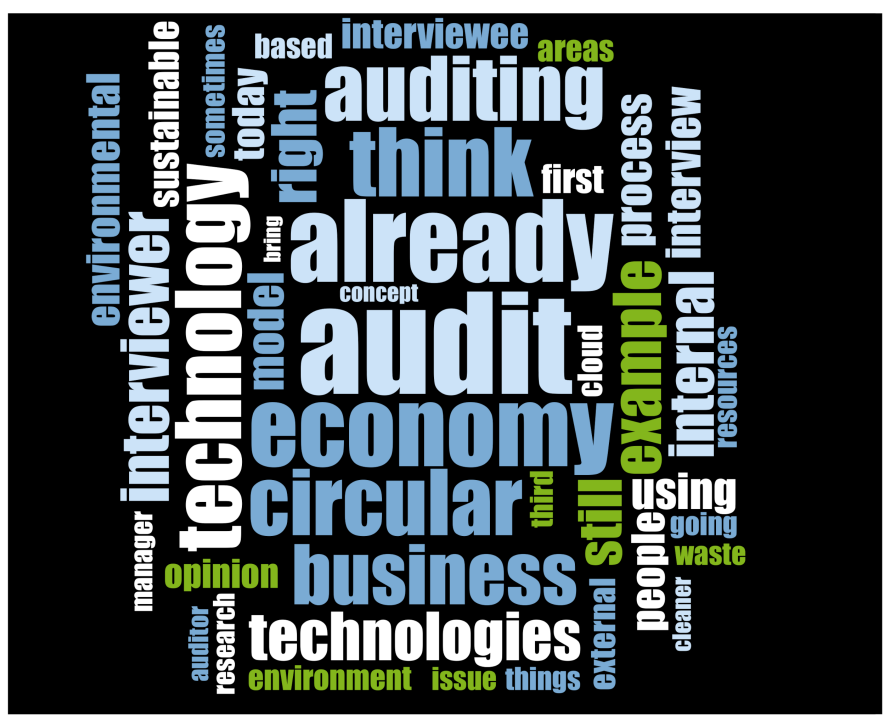

Figure 3. Word clouds.

Additionally, we present the significances encountered through categories herein after referred to as codes in their emerging schemes hierarchically shown in Figure 4 . These suit the representation of this study according to Merriam [44] and King [45] on a categorical analysis that manifests the following reflexivity.

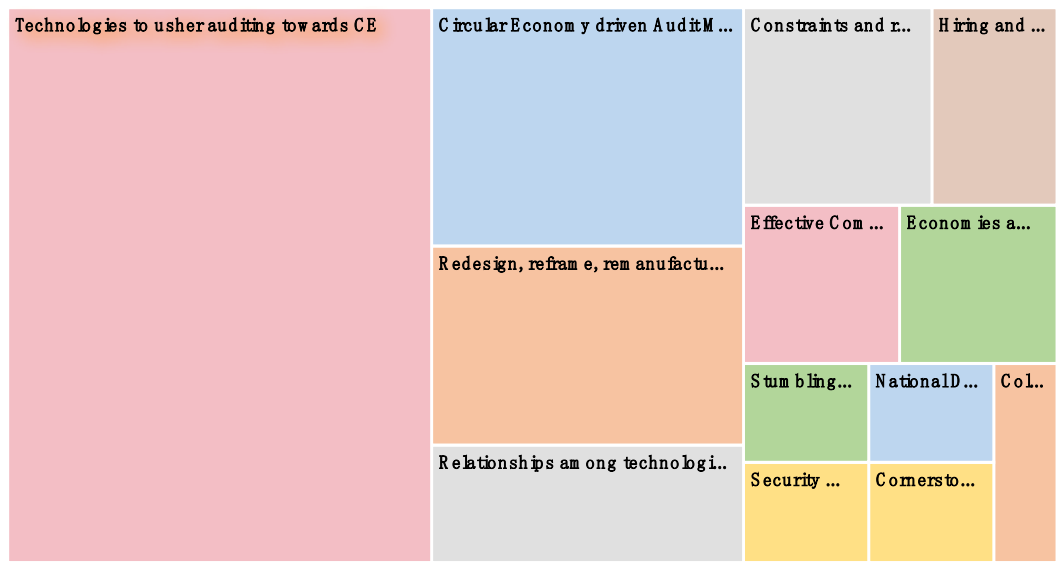

Figure 4. Hierarchy of the codes showing the relationships. 


\subsection{National Database Is Sine Qua Non to Drive Organisation towards CE}

An integrated national database is one of the primordial technologies that will enable organizations to partake in rethinking their business models towards $C E$ whose processes have changed. This is in line with what Patwa et al. [7] commented on, in that the core of CE has changed the development mode. This database should be such as big data that houses every type of data that could be accessed by all stakeholders to assist in redesigning their business models, planning, operation, continuous monitoring, performance evaluation, and business disclosures.

KAG observed that:

The main constraints of the functionality of CEM is not the monitoring aspect held by auditing tools, but the absence of a National Database in Brazil that should consolidate data for every helm of affairs in the nation. Businesses need source data to enhance planning, execution a reporting in a timely basis.

The EU shows an exemplary unified database. Open data and data sharing have been at the crux of European policy for more than two decades now [46].

Yet, according to KAG,

Even though organisations have embraced a significant uptake of technologies for breakthrough of businesses towards $C E$, they have been sluggish to administer their models.

Obviously, the Brazilian government is supposed to dictate the tune, and if this support is withheld administrators could be frustrated with efforts being made to implement CE technologies. Thus, other business aspects could therefore take priority.

In the same vein, to KAG:

The companies which are not mainly pollutant sees the investment in CE to enhance their process as onus.

This is in line with the affirmation of Perera et al. [10] that says that expenditures relating to sustainability practices are still institutional options and they occur based on the demands of shareholders, with the reflection of social expectations. In other words, there should be reason for a mutual gain or win-win in order to invest in CE.

\subsection{Redesign, Reframe, Remanufacture, Reuse of Products in Its Chain}

In the observance of new technologies supporting CEM, businesses should be able to redesign, reframe, remanufacture, and also enhance the reuse of products. JMF notes:

Many people have reframed themselves and created new products. So, I think that this reframing within the pandemic as well as in the circular economy perspective and in terms of sustainability has worried our customers a lot.

Concerning the trend of reuse and repair in businesses, JPA observed:

I audited businesses that work with railway transport, for example, and has a great technology front, algorithmic programs in which trains consume less, monitor and repair the appropriate proportion. This obviously has a cost reduction, which will impact the environment.

In the same line of thought, GPG observed:

The technologies will make things easier as different from traditional way of doing things as organisations reframe their businesses and redesign their processes by adopting technologies such as Big data and, Artificial Intelligence.

Additionally, in the same vein REB observed that auditors also reframe functions:

The data analytics congregates all auditing functions by enabling execution of substantive tests with 100\% sampling coverage with Computer Assisted Audit Techniques (CAAT). Also noted that, it is an advancement when we are able to be efficient when we scale through duplicate tasks. In effect, this jumpstart with technology brings efficiency to auditing. 
In the same line of thought, we think of the consumption in the product chain. Consumers are expected to just buy what is really necessary and not stock up, as has been the culture in some economies. We agree that the environmental and societal impacts of consumption require greater attention and need to be examined in more diverse market contexts [11].

In relation to this, VAD observed:

Here at home we already buy larger packages so as not to buy several small ones. Instead of buying ten detergents, you buy a bigger package, that of five liters of alcohol. But you still have residue on that. So, I don't know if this is where technology could perhaps help $u s$, to have more educational practice, to raise awareness.

In other words, in homes where excessive consumption is observed, there could also be excessive waste, particularly arising from unconsumed products at the end of the month they expire. A look into this culture of uncontrolled consumption will eventually assist in the CE mode of life.

\subsection{Technologies to Usher Auditing towards CE}

\section{According to ORA:}

I have asked my partner, who wrote specifically about the circular economy, about the inclusion of blockchain. Solutions that are bringing security, are bringing an absurd level of reliability to the business cases that are being implemented, are the guarantee that this cyclical model will be solvent, that is, it will be guaranteed forever.

The same respondent cites IoT:

Like self-regulating machines, that controls your energy usage, machines that self-control consumption and that manage to bring solar energy in the perspective of IoT ought to be controlled.

Additionally, ORA mentioned that:

In pursuit of this, there is only one way to bring interaction, cost reduction, integration of everything, which is with a lot of innovation; a lot of technology.

As per JMF:

Concerning audit, our organization had to run after the cloud computing, where it had the ability to place documents from clients.

The same interviewee observed that there is good number of smaller audit firms still working with non-innovative technologies, thereby making them lag behind in view of CE.

HOD observed that the cloud has assisted in the optimization of the processes:

The database which used to be separated into 3 or 4 servers are now consolidated into 1. In this case, every owner has a control over a tree whose dorsal spine helps to minimize interference. In effect, controls that used to be physical is now logical.

Thus, logical security control now becomes more intense, in terms of holding every system owner to periodic accountability for the usage of data, its appropriateness, and the maintenance of its relevance value.

In the same line of thought, REB observed that:

Cloud and particularly Software as a Service (SaaS) intensified actions for efficiency at forefront of business directives and this works well for the auditors.

JMF says:

Each audit company has its own system. Some still use a lot of excel, which are smaller companies, but the bigger ones have to have an audit system where there is a designed methodology towards the CE.

ORA and JMF mention blockchain technologies. JMF, in particular, said: 
There is the blockchain too, but we haven't used it yet. It's all very new but I think it can help a lot, I have heard that some audits have worked a lot with blockchain.

TAA emphasizes the adoption of big data, saying:

The CCIMAR (Audit Unit of Brazilian Marine) realizes continuous auditing in the following areas: Budgetary Execution and Finances, Employee Payroll, Property and Heritage and Bidding and Contracts.

Additionally, he emphasizes that:

We realized tests without interfering in the business routines by manipulating big data with Idea Tools and Python programming tools.

TAA, furthermore, comments on the advantages of the technologies, saying:

Auditing performed with data analytics permits the audit in all the units, with greater frequency and the results being communicated to the management in a timely basis.

Similarly, CRB observed:

Technology will give auditors the pronounced capacity with artificial intelligence to analyse various variables in order to generate more reliable information for decision-taking.

JPA, in the same vein, concludes:

The technologies are such as data analytics, artificial intelligence, powerful databases to mention just a few are already among us and we only need to align our business to it. Auditors have to adjust their tools in order to be more effective in their tasks.

In the same tone, HOD observed:

We use RPA in repetitive processes such as contracts analysis, authorisations with reduced level of risk which does not need a physical interference and we follow the indexes for exceptions and exceptions.

However, in some businesses, people are handicapped. JPA observed that:

There is a desire by the company to start looking at technology, to be able to make more assertive predictions, so to speak more, but today we are still very much in empiricism. We do not have a maturity in this sense. We do not have advanced technologies that assist in numbers, but in operation.

\subsection{Circular Economy Driven Audit Model}

The audit model driven by $C E$ is an innovative type that incorporates all the essence of reuse and no tolerance for waste and breeds collaborative exercises and complementarianism. For instance, the independent auditor will now have to pay more attention to the work done by the internal auditors in order to avoid duplicate efforts.

As observed by ORA:

We already have an audit model totally renewed by innovation, eliminating the effort through the GRC. Management, Risk and Compliance processes are already almost all automated processes, almost all controlled by workflow, and all managed.

In the same line of thought, HOD observed:

Global Risk Compliance as a technology is already being used by our organization. The three levels of assessment which are management review, compliance and internal control monitoring, and internal audit are maintained considering the risk appetite of the management.

Yet ORA said:

The Big 4 are now entering the Cloud, SAS, and process automation models to understand the new business. I believe that due to the conversations we are having with engagement leaders, they now understand that the audit models because of their low margins also need a new model. 
So far, ORA concludes:

I have no doubt that it will be through a great workflow, a great new and agile process. And then almost in sequence with a blockchain underneath guaranteeing security and traceability.

5.5. Efficiency of Accounting and Auditing Processes

As per HOD,

We use Watson for automation and revision of contracts and for credit analysis. Data mining have been automated. Functions such as Human Resources management and also change management are receiving finishing retouches for their implementation.

Obviously, this emphasizes the diversity of the usage of technologies, bringing efficiency into the accounting and auditing functions.

JPA commented on AIS and sustainability, saying:

With the new SAP and it innovations, a merchandise that arrives in the truck has its Invoice launched and accessed through the system, nothing more manual. And enough for the accountant to do analysis. For me, this is all sustainability.

Additionally, according to HOD:

As pertaining to Blockchain, departments normally give signoffs for the margin of collaterals and this normally takes 2 days for approval. The current process with AI in its optimisation now takes a couple of minutes.

In the same line of thought, JPA observed that:

In the past we had a trainee, two full days, processing information and a whole week doing a depreciation calculation on spreadsheet. This has an impact on consumption, paper, electricity, computers. I think it also has a social impact, because people today can have a better quality of life with technology.

JPA also mentioned that EY was able to do a one hundred percent audit. Instead of doing a global calculation of amortization, it did a hundred percent test. This even changed their report regarding the main audit matters.

\subsection{Remote Auditing and Less Burnout Come to Stay}

A recent phenomenon concerning COVID-19 in auditing has to do with remote procedures. According to JMF:

I usually joke that the audit dinosaurs did not imagine working remotely. We all working remotely is not a very easy task. But on the other hand, it broke a very big taboo in the area of auditing and accounting.

Not imagining that a pandemic would oblige everyone to work from home, E\&Y envisioned this phenomenon of the home-office in early 2016, when it scrapped many offices of its collaborators till the partnership level. Exceptionally, members of the teams had to make reservations to use a space in the office when they had meetings with clients and collective training which could be held virtually.

As observed by JMF:

We saw that we can be more productive and with that we generate savings even for the company in the sense that the employee working at home will have less Burnout.

\subsection{Effective Communication with the Governments}

In line with this, $\mathrm{CRB}$ observed:

In these channels, employees and employers will effectively be able to communicate with the government in a unified manner by complying with different regulations.

Additionally, GPG observed: 
Remote sensing and Satellite Imagery processing is been intensely used in this new era by the governments and particularly the municipal governments to assist in stipulating Property Taxes by accurately mapping the extension of lands and constructions.

In fact, this accuracy in property mapping with satellite imagery has two gains for the government: firstly, with the access to very remote areas, which could be very risky, and secondly with the preciseness of the measurement, which may not be arguably contested by anyone.

\subsection{Security Awareness}

As every business incorporates the use of ICT, security policies ought to be revigorated to embrace the digital chain of circular economy. Digital chain-e-commerce through ebanking and e-signature-is one of the most characteristic features of the contemporary global economy [47].

As mentioned by JMF:

I think you must be following the General Law of Data Protection (LGPD-Lei Geral de Proteção de Dados) in relation to personal data. All companies need to adapt to this. Many don't even know what it is. I think this will help my clients a lot to have their data protected. This will help companies, for example, because in this case, personal data is confidential data from both employees, customers, suppliers. And then this circular economy arises because everything today is technology.

Thus, with every user whatever their intentions having access to databases, all laws that safeguard assets have to be in place. Historically, enforcements have been problematic, but the related bodies would have to tighten them up to achieve societal comfort.

\subsection{Constraints and Resistance of Technology Breakthrough for Elderly Auditors}

JMF observed that:

It is exactly what has been discussed about circular economy. I think older auditors are actually more aloof. Here I work with slightly older people, but anticipating the generation of directors that is coming, we have to think a lot about this sustainable economy.

In the same line of thought, JPA observed:

The partner who has thirty years of experience, is still very attached to older tests and this ends up losing the attraction. At the end of the day, we have several technologies developed, but whoever is at the front ends up being a little resistant to using it.

In effect, as the responsibilities of an engagement lies within the partners, it is expected that this gives the tone at the top and lay examples for the implementation of technologies which are sine qua non for auditing.

\subsection{Economies and Businesses Lagging Behind in Implementation of CE Standards KAG mentioned that:}

The organisations which are not effectively degradants of environment does not see any motive in investing in technologies towards circular economy inasmuch as they consider such spending as merely onus to the business.

In the same vein, KAG emphasized that:

Brazil seems to be lagging behind in the implementation of circular economy models that is sufficient for the country comparably with the peers. The ministry of environment has interest in studies that explores the circular economy technologies. However, the government efforts have not been up to the tasks.

Similarly, this has a reflection on the operational functions. JPA noted:

I would say that in Controllers department, specifically we are still crawling, it is the controller that does not have artificial intelligence, no algorithm. But when I look more 
at the side of financial planning, for example, there is already a discussion of how to eventually create an algorithm to be able to make a forecast, more accurately, for example.

In other words, the department such as the controllers concerned about internal controls that sets the pace for cost minimization and the optimization of resources supposed to think about agile processes that are enhanced by the implementation of technologies.

\subsection{Hiring and Training of Users of CE Sustainable Technology}

It is important to signal the need to train auditors and update their skills, besides other interested users, in order to effectively harness the resources available from CE sustainable technology.

According to GPG:

However, training of users of technology in CE is necessary. Big organisations are already doing that. But the majority is still lagging behind particularly the SMEs.

In the same vein, concerning the training of auditors, JPA observed that:

They are going to hire an auditor who is in his first year at college, because a trainee was much more to do spreadsheets, something more operational, which today is unnecessary due to technology. It has a social impact.

\subsection{Stumbling Blocks to Implementing Auditing Sustainable Technologies towards CE}

\section{According to VAD:}

There is the believe that when we talk about sustainability there is a commercial issue involved. That is why I see that it is a situation where there is a very large conflict of interest from players with diverse interest. Global Reporting Initiative (GRI) investors are responsible for investment principles.

In general terms, the interviewees site the technologies summarized in Figure 5 that are either being used or being planned for use in their engagements.

\begin{tabular}{lc}
\hline $\mathbf{N o}^{\circ}$ & CE Auditing Technologies/Approaches \\
\hline 1 & National database and management systems \\
\hline 2 & Digitalization technologies and paperless audit as an enabler of CE \\
\hline 3 & AI and RPA enable the automation of repetitive auditing processes \\
\hline 4 & Remote auditing/assessment using TEAM, Zoom \\
\hline 5 & ISO 9001, ISO 14001 template analysis \\
\hline 6 & Remote sensing for geoprocessing and observatory approaches \\
\hline 7 & Drone fly-over physical stock count approach avoiding in loco visit \\
\hline 8 & GPS satellite mapping/tracing for fixed assets \\
\hline 9 & RFID mapping/tracing of documentary evidence \\
\hline 10 & IaaS, SaaS, DaaS options for cloud computing \\
\hline 12 & Computer operation continuous algorithmic alerting for anomaly \\
\hline 13 & Blockchain resources \\
\hline 14 & Decentralized security administration \\
\hline 15 & E-commerce, E-banking and E-signature. \\
\hline
\end{tabular}

Figure 5. List of technologies used or being planned for use in auditing during CE.

Thus, in another perspective of analysis, in a nutshell we sketch out additional categories to facilitate understanding. This utilizes first-order categories and axial coding, as suggested by Strauss and Corbin [48], for broader detail in Figure 6. 


\begin{tabular}{|c|c|c|c|}
\hline 1st Order Categories & Analyses & \begin{tabular}{|lllll} 
Highlighted & Axial & or & $2^{\text {nd }}$ & order \\
Categories & &
\end{tabular} & $\frac{\text { Respo }}{\text { ndents }}$ \\
\hline $\begin{array}{ll}\begin{array}{l}\text { Database } \\
\text { systems }\end{array} & \text { management } \\
\end{array}$ & $\begin{array}{l}\text { Intergovernmental initiative is called for in } \\
\text { this moment in order to set the pace for the } \\
\text { building of the necessary technology which } \\
\text { is the basis of recognition of peers, raw } \\
\text { materials and labour involved in product } \\
\text { design }\end{array}$ & $\begin{array}{l}\text { Immediate challenge for } \\
\text { implementation of circular economy. }\end{array}$ & \begin{tabular}{|l} 
E1 \\
E1
\end{tabular} \\
\hline $\begin{array}{l}\text { Image portrayed by the } \\
\text { players }\end{array}$ & $\begin{array}{l}\text { Nice Sustainability Management discourse. } \\
\text { But the practice does not match what is } \\
\text { recorded in the financial statements. }\end{array}$ & $\begin{array}{l}\text { Discourses needs to reflect the reality } \\
\text { and embrace the demand for the } \\
\text { current sacrifice }\end{array}$ & E8 \\
\hline $\begin{array}{ll}\text { Information } & \text { Security } \\
\text { management } & \end{array}$ & $\begin{array}{l}\text { As every corporation is going internet and } \\
\text { coupled with the COVID-19 safeguard of } \\
\text { assets and personal data becomes more } \\
\text { relevant }\end{array}$ & \begin{tabular}{lll|} 
Data protection & enhances & $C E$ \\
Emission Reduction & Credi effective \\
implementation & &
\end{tabular} & $\overline{E 2}$ \\
\hline $\begin{array}{l}\text { Governance } \\
\text { Compliance }\end{array}$ & $\begin{array}{l}\text { The remodelling of the business models, } \\
\text { structures and function such as auditing } \\
\text { becomes a sine que non condition to move } \\
\text { to CEM }\end{array}$ & $\begin{array}{l}\text { Rethinking the business from bottom- } \\
\text { up approach as the best bet becomes } \\
\text { the end-user of the products. }\end{array}$ & E9 \\
\hline The tone at the top & $\begin{array}{l}\text { The management does need to give the } \\
\text { right policies to follow suite with } \\
\text { implementation of CE technologies }\end{array}$ & $\begin{array}{l}\text { CEEmission Reduction Credi is an } \\
\text { Irreversible trend in the } \\
\text { implementation of current business. }\end{array}$ & E4 \\
\hline $\begin{array}{l}5 \mathrm{G} \text { Technology based } \\
\text { projects }\end{array}$ & $\begin{array}{l}\text { We are seemed to be pushed to the next } \\
\text { generation of computers. Those behind will } \\
\text { be inevitably pulled out in this race towards } \\
\text { CE. }\end{array}$ & $\begin{array}{l}\text { The push pull effect of adherence to } \\
\text { technologies by organisations to meet } \\
\text { up standards of CE. }\end{array}$ & E4, E8 \\
\hline $\begin{array}{l}\text { Cost minimisation and } \\
\text { everyone gains }\end{array}$ & $\begin{array}{l}\text { An interviewee would say, you do not need } \\
\text { to pay for the whole year for a cloud if you } \\
\text { do not use the resources. }\end{array}$ & $\begin{array}{l}\text { Commitment to reducing cost from } \\
\text { producer/consumer loop } \quad \text { back } \\
\text { perspective. }\end{array}$ & E1, E7 \\
\hline Auditors to buckle up & $\begin{array}{l}\text { Aged auditors or young, there does not } \\
\text { seem to be any chance to think otherwise } \\
\text { for acquaintances of renewed auditing } \\
\text { methodologies. }\end{array}$ & $\begin{array}{l}\text { No myopic look at Auditing revised } \\
\text { methodologies to keep pace with } \\
\text { CEM. }\end{array}$ & E3 \\
\hline $\begin{array}{l}\text { Tools to track frauds by } \\
\text { auditors }\end{array}$ & $\begin{array}{l}\text { Blockchain mathematical algorithm is now } \\
\text { being used by the auditors. Enables them to } \\
\text { verify that procedures are being adhered to } \\
\text { and used consistently. }\end{array}$ & $\begin{array}{l}\text { Very difficult to corrupt the built-in } \\
\text { programs under blockchain }\end{array}$ & E9 \\
\hline Resilience and resistance & $\begin{array}{l}\text { The barriers to implementation of the } \\
\text { technologies have to be termed as } \\
\text { surmountable in every phase of technology } \\
\text { breakthrough. }\end{array}$ & $\begin{array}{l}\text { Continuous enhancement will lead } \\
\text { the battle of every roles towards } C E \text {. }\end{array}$ & E2, E3 \\
\hline Auditor's place in CE & $\begin{array}{l}\text { Auditors are convincing the management to } \\
\text { implement the technologies with proven } \\
\text { standard that helps business objectives }\end{array}$ & $\begin{array}{l}\text { Auditor becomes protagonist to bridge } \\
\text { gaps of inevitable changes. }\end{array}$ & E9 \\
\hline $\begin{array}{l}\text { Push towards } 5 \mathrm{G} \text { era } \\
\end{array}$ & $\begin{array}{l}\text { In banking sector in terms of providing } \\
\text { services, digitizing documents, facilitating, } \\
\text { Brazil will now enter the era of } 5 \mathrm{G}\end{array}$ & $\begin{array}{l}\text { We are already pushing forward in } 5 G \\
\text { and have to prepare for } 6 G \text {. }\end{array}$ & E8 \\
\hline
\end{tabular}

Figure 6. First-order categories and axial for the perspectives of $\mathrm{CE}$ from experts.

\section{Discussion}

All said and done, the results demonstrate that the relationship between auditing and circular economy is built on the rock of sustainable technologies which is yet under development in various facets of organization. To this extent, no significant differences can be observed from the data captured and analyzed showing evenhandedness among respondents which has proven that technology is the Achilles heel in pursing the mission of $\mathrm{CE}$. Technology-CE are tightly associated. In fact, technology maturity could be termed as associated with $\mathrm{CE}$ uptake. Thus, in respect of this, we draw on the following additional emerging codes for reflexivity.

\subsection{Bone of Contention for the Implementation of Sustainable Technologies for Auditing in CE}

There are lots of discussions surrounding the implementation of sustainable technologies which raises conflicting positions between the auditor and auditee. Bourdieu [39] questions if change exists both in technological developments and in ways of living personal lives, why do these seem to occur in parallel but remain relatively disconnected from one another? It is in this disconnection that lies human disagreement, which in turn hampers human evolution, notwithstanding a healthy contrarianism.

In Brazil, organizations which are less pollutant and mere compliant of environmental rules do not see it as a technology that leads to profitability or revenue optimization. Probably an awareness program is necessary to propagate knowledge of the relationships of economic, social, and environmental rules and the societal impact on wellbeing.

In the Brazilian scenario, reverse logistics has just begun to gain ground in industry. This means that there is still much to develop and also manifest in this aspect of technology for $\mathrm{CE}$, as local experiences are yet to fully surface. 


\subsection{Light that Flicker at the End of Tunnel}

The emphasis on labor in CEM and no more on raw materials creates a hope for the development of labor itself. Probably, this shift will reorientate the strategies towards reduction in unemployment which has been the social problem to all economies.

Thus, the auditing technologies that supports their competencies to enhance circular economy approaches in auditing should borrow a leaf from the cleaner production auditing standards. These standards, in essence, allow auditors to adopt traditional analytical procedures, internal control reviews, and substantive procedures.

According to De Wet [49], two analytical techniques can be used to quantify the relationships between technology and an enterprise. Firstly, the Technology Space Map quantifies the technological capability of people in the enterprise where the life cycle phases, the product breakdown and the organizational structure are evaluated and secondly, the Technology Balance Sheet and Income Statement.

\subsection{Efficiency of Management Functions}

From an economic perspective, the effectiveness of the use of these technologies to support auditing will definitely reflect on its contribution towards a viable CE, guided by management directives. Laclau and Mouffe [38] potentials of hegemonic porosity, articulated through the voices, spaces, and politics. Notwithstanding, the technologies are contributing to the utmost efficiency of the teams.

The technological resources applied in AI are not necessarily in first place to comply with the circular economy, but to improve the approach and gain efficiency at a lower cost, and even because for some cases it would be impossible to maintain an efficient audit sample, in the face of such large and with different data. At times, this becomes clear in the interviews.

There seems to be a right turn in the order of things considering the challenges posed by implementation of technologies. A good number of tools are enabling the auditors to take advantage of levels two and three of line of defense to adequately plot the risk matrices and draw strategies that increase the internal audit efficiency.

\subsection{Horizon of Technologies to Support Auditing in CE}

A couple of technologies have been mentioned, and we draw upon them for the further reflexivity of this horizon. Additionally, in order to support this trend, we triangulate with items proposed by Imperial College [50] on disruptive technologies which have been subjectively categorized in groups of data ecosystem, smart planet, extreme automation, human argumentation, and human-machine interactions. This is further shown in Figure 7 for a detailed assessment.

\begin{tabular}{|l|l|l|l|l|l|}
\hline AIS & IT & Auditing & $\begin{array}{l}\text { Decision } \\
\text { taking }\end{array}$ & Learning & $\begin{array}{l}\text { Innovative } \\
\text { Cleaner } \\
\text { Production } \\
\text { Auditing }\end{array}$ \\
\hline Distributed Ledgers & $\begin{array}{l}\text { Self-Writing } \\
\text { Softwares }\end{array}$ & $\begin{array}{l}\text { Peer-to-Peer } \\
\text { Assessment }\end{array}$ & $\begin{array}{l}\text { Predictive } \\
\text { Based } \\
\text { Systems }\end{array}$ & $\begin{array}{l}\text { Automated } \\
\text { Knowledge } \\
\text { Discovery }\end{array}$ & $\begin{array}{l}\text { Deep Ocean } \\
\text { Wind farms } \\
\text { auditing }\end{array}$ \\
\hline Cryptocurrencies & Blockchain & $\begin{array}{l}\text { Autonomous } \\
\text { Robotic Mapping/ } \\
\text { Tracing }\end{array}$ & AI Advisors & $\begin{array}{l}\text { Emotionally } \\
\text { Cognitive } \\
\text { Machines }\end{array}$ & $\begin{array}{l}\text { Vertical } \\
\text { Agriculture } \\
\text { Auditing }\end{array}$ \\
\hline Cloud computing & $\begin{array}{l}\text { Balloon- } \\
\text { powered } \\
\text { Internet }\end{array}$ & $\begin{array}{l}\text { Drone remote } \\
\text { sensing Delivery }\end{array}$ & $\begin{array}{l}\text { Printing an } \\
\text { 3D } \\
\text { Imaginary }\end{array}$ & $\begin{array}{l}\text { Thought } \\
\text { Control } \\
\text { Interfaces }\end{array}$ & $\begin{array}{l}\text { Water } \\
\text { harvesting } \\
\text { auditing }\end{array}$ \\
\hline $\begin{array}{l}\text { Integrated Reporting } \\
\text { Networks }\end{array}$ & $\begin{array}{l}\text { Wireless } \\
\text { ICT }\end{array}$ & $\begin{array}{l}\text { Programmable } \\
\text { Continuous } \\
\text { Auditing }\end{array}$ & $\begin{array}{l}\text { Neural } \\
\text { Networks }\end{array}$ & $\begin{array}{l}\text { Public Mood } \\
\text { Monitoring }\end{array}$ & $\begin{array}{l}\text { Remote } \\
\text { Sensing } \\
\text { /Auditing }\end{array}$ \\
\hline $\begin{array}{l}\text { Global Standards } \\
\text { integration }\end{array}$ & $\begin{array}{l}\text { Data Storage } \\
\text { DNA }\end{array}$ & $\begin{array}{l}\text { Autonomous } \\
\text { Airborne } \\
\text { monitoring }\end{array}$ & $\begin{array}{l}\text { Intention } \\
\text { Decoding } \\
\text { Algorithms }\end{array}$ & $\begin{array}{l}\text { Satellite } \\
\text { Imagery }\end{array}$ \\
\hline
\end{tabular}

Figure 7. Horizons of technologies to support auditing in CE. 
6.5. Relationships between CE Sustainable Technologies and Auditing Structure Now and in the Future

From a sociological perspective, we represent the discourses that concern the sustainable technologies and their impact on financial auditing structures, addressing the redesign of societal engagements and their value network aimed to suite the promising paradigms of CE. This eventually has a relationship with other categories, as shown in Figure 8.

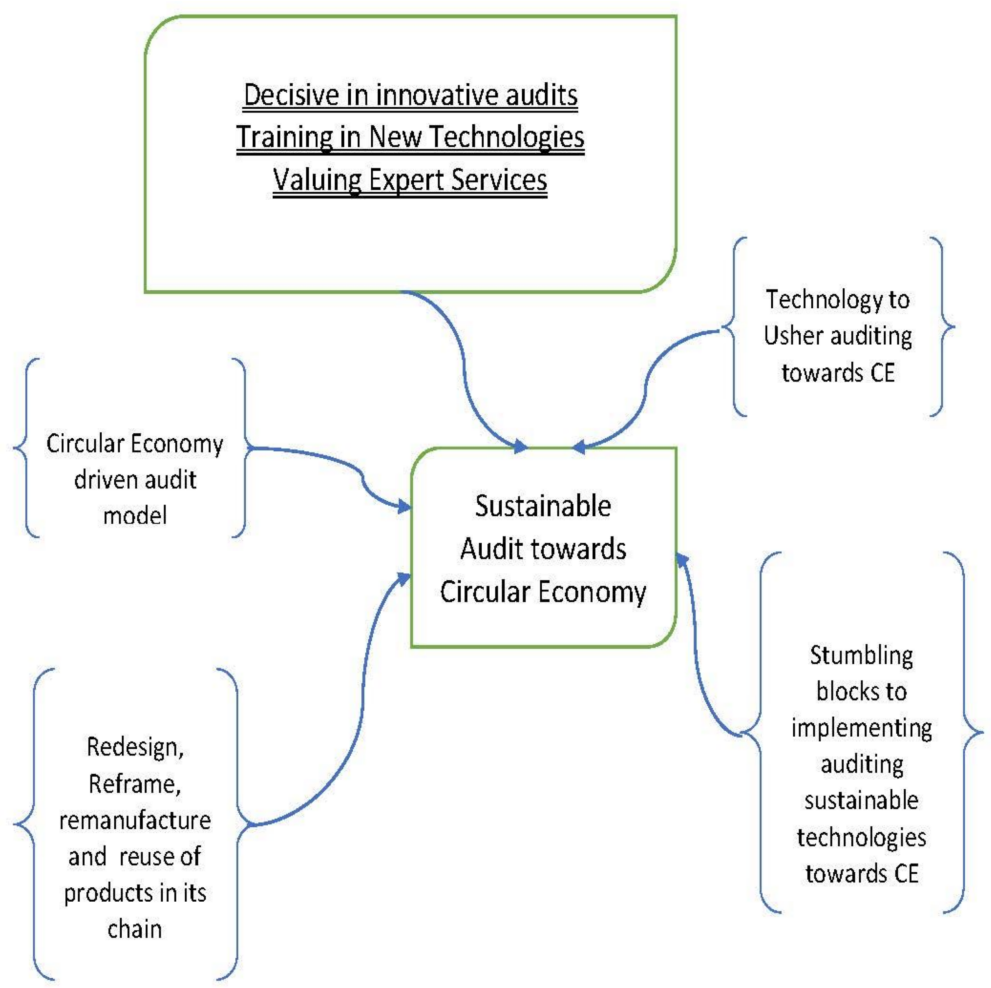

Figure 8. Relationships of technologies and audit models with sustainability.

This, in our view, posits a high-level overview of auditing engagement, planning, analytical procedures, internal control assessments, and substantive procedural tasks.

Under a high-level overview, the ethical standpoint and organizational policies have to exert monitoring control over transactions from computer operations. In effect, in order to uphold an ethically supported engagement, the prior exercise of the verification of auditor independence has to occur from time to time because of the dynamism of businesses. This must be verified to ensure that no insider information is let loose to an unauthorized member of the engagement team or an outsider, and access to information will have to be on a need-to-know basis. This has to be exercised also over the activities of the auditors on a supervisory basis. This becomes important because, instead of working in a test environment, the auditors will be performing their evidence gathering in the live environment of their clients.

Thus, the planning tasks with technological resources becomes easier. With the knowledge of exploring an integrated database, the understanding of the control environment, the identification of control activities, and the mapping of risks are enhanced. Effectively, the procedures to be verified in order to mitigate identified risks becomes a mere automated process which, through machine learning, could be continuous or a pattern definition to meet expectations. Under the assessment of analytical procedures, patterns from the predicted and analyzed results from neural networks could guide conclusions in respect of this. Additionally, data from the history of testing could assist in engagement management to establish the level of acceptable risk.

In the same line of discussion in the assessment of internal control, auditors would have to review the policies of IoT in view of mitigating the identified risk for the business. 
IoT enhances circular economy with the devices installed to automatically detect scrap material levels and its management. Additionally, in the production process, IoT identifies a network of companies which take waste materials as raw material for reuse.

Similarly, with the deployment of fifth-generation communication resources, future trends and technologies need to be studied. Zhang et al. [51] drew on state-of-the-art technologies in 5G and indicated the necessity to study 6G, envisioning 6G to include three major aspects—namely, mobile ultra-broadband, super Internet-of-Things (IoT), and artificial intelligence (AI). It is necessary to to emphasize that machine learning will be the future. R, Python, and a host of others are prominent programming languages that ought to be known by the auditors to help their tasks in CE.

From an economic perspective, cloud-based accounting stimulates auditors to review the choices of cloud computing if it contributes to reducing environmental impacts. Cloud computing provides information to interested parties with various strategies, such as Infrastructure as a Service (IaaS) and Software as a Service (SaaS), among others, to disrupt the prevailing business models, thereby employing digitalized data to users with reduced cost and curtailing waste. Service and policy framework, and circular economy are significant enablers connecting CE [52].

Thus, using data analytics in substantive reviews, unstructured or structured data are addressed in a CE environment. For instance, "Drone as a Data Service" and "Confirmation as a Service" are being contracted to cover the task for substantive testing. In this case, auditors would have to apply the rules that have to do with expert support as guidance. When Alteryx is used for qualitative analysis, for instance, workflow diagrams and the mapping of tasks could be harnessed by eliminating manual activities.

Similarly, cognitive computing in decision-oriented auditing assists in mitigating risks with the selected substantive procedures. Thus, in order to perform further risk-based audit analyses, auditors would have to generate reports from databases, using either Tableaux, ACL, or IDEA to perform auditing interrogation for further exercises with an aim to analyze exceptions. Remote Sensing Optical Filters (RSOF) is one of the resources that operationalize remote sensing and environmental monitoring. Particularly for green accounting, this can be used with drones to fly over acres of cultivated lands and also deeper mines to enable the auditor perform mapping. In another analogy, during forensic accounting this would probably allow the assuror to trace some anomaly reported by whistleblowers on plantations or a verse land.

Eventually, holding to the political perspective, auditors can be said to already be inserted in circular economy roles inasmuch as they have acted as some of the protagonists of its implementation. This role is active particularly when it comes to the forefront of assessing investment opportunities in investment committees with peers and also citing the advantages accrued by same auditing. Thus, auditing firms seems to be making all ends meet to effectively contribute in their own way in the transition towards a CE.

Indeed, an organization may not be the leader among the players of this movement towards $\mathrm{CE}$, but considering the pros and cons, no rightful organization would be left out in this wave of cultivating a more habitable environment for all.

\section{Conclusions}

This paper provides an understanding of the relationships between sustainability technologies, auditor transition, and circular economy models. The impact of sustainable technology has long been felt by either the auditee or auditor to be towards CE.

The analysis revealed that the sufficiency of reusing, recycling, repairing, and remanufacturing, as foreground sustainable notions of $\mathrm{CE}$, will mediate technology usage in auditing hence forth. This serves as a hint to practitioners and those in teaching and as an influence on public policy makers. De facto, this will permeate planning, execution, and auditing reporting, so both academia and policy makers are forewarned in their approaches towards CE. 
Additionally, with the shift in emphasis from raw materials to labor, there is likely going to be more investments in the development of Human Resources (HR). This will be the light that flickers at the end of tunnel regarding the issue of unemployment that troubles all societies in this era.

Based on our investigations, the sustainable technologies which will usher auditing towards CE are national database and management systems, digitalization technologies, $\mathrm{AI}$ and the Robotic Process Automation (RPA) enablers for the automation of repetitive auditing processes, remote auditing/assessment using TEAM, Zoom, ISO 9001, ISO 14001 template analysis. Others include remote sensing for imagery geoprocessing and observatory approaches; drone fly-over physical stock or fixed asset count approaches avoiding in loco visits; GPS satellite mapping/tracing; RFID mapping/tracing of documentary evidence; IaaS, SaaS, and DaaS options for cloud computing, Neural continuous algorithmic and Blockchain resources, IoT integrating appliances, applications, and processes. This finding is in line with the argument for innovative technologies to usher in auditing, considering its monitoring tools toward an effective CE environment.

De facto ICT resources such as artificial intelligence and remote sensing optical filters which operationalize remote sensing and environmental monitoring have been used to minimize cost, and this in effect reverts back to users in terms of reductions in auditing fees. It may thus be concluded that auditing technologies are growing, aiming at implementing $5 \mathrm{G}$ technologies into their CE models.

Our understanding of sustainable auditing technology towards CE identifies the relationships in the emerging codes underlying: national databases as sine qua non to drive organizations towards CE; redesigning, reframing, remanufacturing, reusing in the product chain; technologies to usher auditing towards CE; circular economy-driven audit mode; efficiency of accounting and auditing processes; remote auditing and less burnout come to stay; effective communication with the government and security consciousness now being mandatory. Others include constraints and the resistance to technology breakthroughs for elderly auditors; economies and businesses lagging behind in their implementation of $\mathrm{CE}$ standards; the hiring and training of the users of CE sustainable technology; stumbling blocks to implementing auditing sustainable technologies towards CE.

In our view, these findings demonstrate a significant uptake of innovate technologies being implemented for the enhancement of auditing, even though some economies are at the initial stages of implementation. Though some actors are lagging behind, auditors being protagonists of assurance of sustainability have to instill technological resources that make them follow the trends of CE. This coincides with the premise of this research, which states that the relationship between auditing and circular economy is built on the rock of sustainable technology which is yet under development in various facets of organizations.

Overall, looking from a future perspective, it is not uncertain that the world of auditing will take note from the lessons of the phenomenon of the COVID-19 pandemic to accelerate the uptake of these technologies. One of the few silver linings of this unprecented COVID19 pandemic is that even in emerging countries people realize how crucial it is to be innovative with technology, and CE is thus gaining from this. This is also true inasmuch as the auditing firms among others are already thinking of the institutionalization of the reduction in structures by collaborating in the building of home-office facilities. Therefore, academia and policy makers are called upon to explore the impact of these technologies on efforts to build a circular economy.

Finally, as a suggestion for future research, we recommend investigating topics such as the relationships between investments in human resources and the acceleration of the transition towards CE. Another could be a discourse analysis of the implementation of CE while building on structuration theory. 
Author Contributions: J.O.I. and W.L.S.; methodology, J.O.I.; software, V.G.S.; validation, L.R.; formal analysis, L.R. and V.G.S.; investigation, L.R.; resources, V.G.S.; data curation, L.R.; writingoriginal draft preparation, V.G.S.; writing—review and editing, J.O.I.; visualization, W.L.S. and V.S.; supervision, J.O.I.; project administration, J.O.I. All authors have read and agreed to the published version of the manuscript.

Funding: This research received no external funding.

Institutional Review Board Statement: Not applicable.

Informed Consent Statement: Not applicable.

Data Availability Statement: No new data were created or analyzed in this study. Data sharing is not applicable to this article.

Conflicts of Interest: The authors declare no conflict of interest.

\section{References}

1. Stahel, W.R. The circular economy. Nature 2016, 531, 435-438. [CrossRef] [PubMed]

2. Korhonen, J.; Honkasalo, A.; Seppala, J. Circular Economy: The concept and its limitations. Ecol. Econ. 2018, 143, 37-46. [CrossRef]

3. Liu, Y.; Bai, Y. An exploration of firms' awareness and behavior of developing circular economy: An empirical research in China. Resour. Conserv. Recycl. 2014, 87, 145-152. [CrossRef]

4. Kirchherr, J.; Piscicelli, L.; Bour, R.; Kostense-Smitb, E.; Muller, J.; Huibrechtse-Truijens, A.; Hekkert, M. Barriers to the circular economy: Evidence from the European Union (EU). Ecol. Econ. 2018, 150, 264-272. [CrossRef]

5. Ranjan, J. Business intelligence: Concepts, components, techniques and benefits. J. Theor. Appl. Inf. Technol. 2005, 9, 60-70.

6. Gale, F.; Ascui, F.; Lovell, H. Sensing reality? New monitoring technologies for global sustainability standards. Glob. Environ. Polit. 2017, 17, 65-83. [CrossRef]

7. Patwa, N.; Sivarajah, U.; Seetharaman, A.; Sarkar, S.; Maiti, K.; Hingorani, K. Towards a circular economy: An emerging economies context. J. Bus. Res. 2020. [CrossRef]

8. Nikonorova, M.; Imoniana, J.O.; Stankeviciene, J. Analysis of social dimension and well-being in the context of circular economy. IJGW 2020, 21, 299-316. [CrossRef]

9. Murray, A.; Skene, K.; Haynes, K. The circular economy: An interdisciplinary exploration of the concept and application in a global context. J. Bus. Ethics 2017, 140, 369-380. [CrossRef]

10. Perera, L.C.J.; Gonçalves, R.; Antunes, M.T.; Imoniana, J.O. Sustainable practice and business profitability in Brazil. JIBE 2011, 11, 14-24. [CrossRef]

11. Osburg, V.S.; Davies, I.; Yoganathan, V.; Mcleay, F. Perspectives opportunities and tensions in ethical and sustainable luxury: Introduction to the thematic symposium. J. Bus. Ethics 2020. [CrossRef]

12. Deloitte. Overview of Circular Economy Business Models. 2020. Available online: https://www2.deloitte.com/content/dam/ Deloitte/fi/Documents / risk/Circular\%20economy\%20FINAL\%20web.pdf (accessed on 20 October 2020).

13. Zero Waste Scotland. What Are Circular Economy Business Models? 2020. Available online: https: / www.zerowastescotland. org.uk/content/what-are-circular-economy-business-models (accessed on 19 September 2020).

14. Sullivan, J.; Hussain, B. How Technology Unlocks New Value from the Circular Economy. 2020. Available online: http: / / www.greenbiz.com (accessed on 28 August 2020).

15. Sarkis, J.; Zhu, H. Information Technology and Systems in China's Circular Economy: Implications for Sustainability. 2020. Available online: http:/ / ssrn.com/abstract=1122865 (accessed on 27 August 2020).

16. Hatzivasilis, G.; Fysarakis, K.; Soultatos, O.; Askoxylakis, I.; Papaefstathiou, I.; Demetriou, G. The industrial internet of things as an enabler for a circular economy Hy-LP: A novel IIoT protocol, evaluated on a wind park's SDN/NFV-enabled 5G industrial network. Comput. Commun. 2018, 119, 127-137. [CrossRef]

17. Pagoropoulos, A.; Pigosso, D.C.A.; McAloone, T.C. The emergent role of digital technologies in circular economy: A review. Procedia CIRP 2017, 64, 19-24. [CrossRef]

18. Bressanelli, G.; Adrodegari, F.; Perona, M.; Saccani, N. Exploring how usage-focused business models enable circular economy through digital technologies. Sustainability 2018, 10, 639. [CrossRef]

19. Castka, P.; Searcy, C.; Fischer, S. Technology-enhanced auditing in voluntary sustainability standards: The Impact of COVID-19. Sustainability 2020, 12, 4740. [CrossRef]

20. Kirchherr, J.; Reike, D.; Hekkert, M. Conceptualizing the circular economy: An analysis of 114 definitions. Resour. Conserv. Recycl. 2017, 127, 221-232. [CrossRef]

21. Geissdoerfer, M.; Savaget, P.; Bocken, N.M.P.; Hultink, E.J. The circular economy-A new sustainability paradigm. J. Clean. Prod. 2017, 143, 757-768. [CrossRef]

22. Raschke, J.; Walsh, K. Sustainable development for digital transformation through identity governance and administration. ISACA J. 2019, 5, 1-11.

23. Antikainen, M.; Usitalo, T.; Kivikytõ-Reponen, P. Digitalisation as an enabler of circular economy. Procedia CIRP 2018, 73, 45-49. [CrossRef] 
24. Imoniana, J.O. Auditoria: Planejamento, Execução e Reporte; Atlas: São Paulo, Brazil, 2019.

25. ISO 19011 Guidelines for Auditing Management Systems; ISO: Geneva, Switzerland, 2018.

26. Imoniana, J.O.; Soares, R.R.; Domingos, L.C. A review of sustainability accounting for emission reduction credit and compliance with emission rules in Brazil: A discourse analysis. J. Clean. Prod. 2018, 172, 2045-2057. [CrossRef]

27. Boyle, C. Education, sustainability and cleaner production. J. Clean. Prod. 1999, 7, 83-87. [CrossRef]

28. Mol, A.P.J.; Liu, Y. Institutionalising cleaner production in China: The cleaner production promotion law. IJESD 2005, 4, 227-245. [CrossRef]

29. Dobes, V. New tool for promotion of energy management and cleaner production on no cure, no pay basis. J. Clean. Prod. 2013, 39, 255-264. [CrossRef]

30. Peltier, N.P.; Ashford, N.A. Assessing and rationalizing the management of a Portfolio of clean technologies: Experience from a French environmental fund and a World Bank CP demonstration project in China. J. Clean. Prod. 1998, 6, 111-117. [CrossRef]

31. Gawas, A.U. An overview on the evolution of mobile wireless communication networks: 1G-6G. Int. J. Recent Innov. Trends Comput. Commun. 2015, 3, 3130-3133.

32. Gui, G.; Liu, M.; Tang, F.; Kato, N.; Adachi, F. 6G: Opening new horizons for integration of comfort, security, and intelligence. IEEE Wirel. Commun. 2020, 126-132. [CrossRef]

33. Tariq, F.; Khandaker, M.R.A.; Wong, K.; Imran, M.A.; Bennis, M. A speculative study on 6G. IEEE Wirel. Commun. 2020, 27, 118-125. [CrossRef]

34. Arnaboldi, M.; Busco, C.; Cuganesan, S. Accounting, accountability, social media and big data: Revolution or hype. Account. Audit. Account. J. 2017, 30, 762-776. [CrossRef]

35. Fonseca, L.M.; Domingues, J.P.; Pereira, M.T.; Martins, F.F.; Zimon, D. Assessment of Circular Economy with Portuguese Organizations. Sustainability 2018, 10, 2521. [CrossRef]

36. Fonseca, L.M.; Domingues, J.P. Exploratory Research of ISO 14001:2015 Transition among Portuguese Organizations. Sustainability 2018, 10, 781. [CrossRef]

37. Derry, S.J. A fish called peer learning: Searching for common themes. In Cognitive Perspectives on Peer Learning; O'Donnell, A.M., King, A., Eds.; Routledge: New York, NY, USA, 1999; pp. 197-212.

38. Laclau, E.; Mouffe, C. Hegemony and Socialist Strategy: Towards a Radical Democratic Politics, 2nd ed.; Verso: London, UK, 2001.

39. Bourdieu, P. Sociology in Question; Sage Publications: London, UK, 1994.

40. Gill, R. Discourse analysis. In Qualitative Researching with Text, Image and Sound. A Practical Handbook; Bauer, M.W., Gaskell, G., Eds.; Sage Research Methods: London, UK, 2000; pp. 172-190.

41. IIA. Inteligência Artificial e Data Analytics na Quarentena e no Futuro com o Novo Normal. 2020. Available online: https: / / iiabrasil.org.br / / noticia / inteligencia-artificial-e-data-analytics-na-quarentena-e-no-futuro-com-o-novo-normal (accessed on 19 September 2020).

42. ISEAL. Global Membership Organization for Credible Sustainability Standards. 2020. Available online: http://www.isealalliance. org (accessed on 26 August 2020).

43. Imoniana, J.O.; Imoniana, B.B.S. Auditors' career development and personal identity crisis. EuRJ 2020, 23, 565-586.

44. Merriam, S.B. Qualitative Research in Practice. Examples for Discussion and Analysis; Jossey-Bass: San Francisco, CA, USA, 2002; pp. 37-39.

45. King, N. Using templates in the thematic analyses of text. In Essential Guide to Qualitative Methods in Organizational Research; Cassell, C., Symon, G., Eds.; Sage: London, UK, 2004; pp. 256-270.

46. European Data Portal. 2020. Available online: https:/ / www.europeandataportal.eu/en (accessed on 28 September 2020).

47. Sepashvili, E. Digital chain of contemporary global economy: E-commerce through e-banking and e-signature. Econ. Aziend. Online 2020, 11, 239-249.

48. Strauss, A.L.; Corbin, J. Basics of Qualitative Research: Techniques and Procedures for Developing Grounded Theory, 3rd ed.; Sage: Newbury Park, CA, USA, 2008; pp. 1-456.

49. De Wet, G. Features of the Technology Colony; Working Paper ITB2001/1; University of Pretoria: Pretoria, South Africa, 2000.

50. Imperial College. Table of Disruptive Technologies. 2020. Available online: https://imperialtechforesight.com/visions/table-ofdisruptive-technologies-2/ (accessed on 28 August 2020).

51. Zhang, L.; Liang, Y.; Niyato, D. 6G Visions: Mobile ultra-broadband, super internet-of-things, and artificial intelligence. China Commun. 2019, 16, 1-14. [CrossRef]

52. Rajput, S.; Singh, S.P. Connecting circular economy and industry 4.0. Int. J. Inf. Manag. Sci. 2019, 49, 98-113. [CrossRef] 